\title{
Investigation on Mental Health Status of College Students in Independent Colleges
}

\author{
Tianlin Chen*, Xiachao Xie, Jia Liu \\ Jiangxi University of Traditional Chinese Medicine \\ Nanchang, Jiangxi 330004, China
}

\begin{abstract}
This paper aims to explore the mental health status of independent college students. This paper use the Symptom Checklist (SCL-90) as a research tool, and 170 college students from three independent colleges in Hebei and Beijing were randomly selected for the questionnaire survey. The results of the survey showed that the SCL-90 symptom scores of the independent college students were relatively high, and the scores of interpersonal relationship, hostility, somatization, anxiety and compulsive factors were significantly higher than the domestic norm ( $P<0.05$ or $P<\mathbf{0 . 0 1})$. It is concluded that the mental health level of independent college students is generally poor.
\end{abstract}

Keywords-mental health; college students; independent college

\section{INTRODUCTION}

The development of independent colleges in China is changing with each passing day. As the scale of undergraduate education in China continues to expand, the proportion of students in independent colleges among college students has increased. Although the students of independent colleges belong to the group of college students, the educational background, management system, student source and so on are very different from those of ordinary universities due to the particularity of the college. For example, the relevant mental health management mechanism is imperfect, students' basic knowledge is weak, their ability to resist stress is weak, and their self-awareness is strong, etc. The above situation makes the group of independent college students have lower mental health, which indicates that there are still many aspects to be improved in the mental health management of the independent colleges in China.

\section{OBJECTS AND METHODS}

\section{A. Object College}

Students from three independent colleges in Beijing and Hebei were selected as survey objects, and random sampling was adopted for the survey. A total of 180 questionnaires were issued, of which 170 were valid, with an effective rate of 94.4\%. The respondents included 103 males and 67 females. There are 24 freshmen, 30 sophomores, 51 juniors and 65 seniors.

\section{B. Methods}

The Symptom Checklist 90(SCL-90) was used for measurement. The scale was developed by Derogatis L.R. in 1975, and it is one of the most famous mental health test scales in the world. It is also the most widely used outpatient examination scale for mental disorders and psychological diseases, the scale was divided into 9 basic symptom factors, namely somatization, compulsion, interpersonal sensitivity, depression, anxiety, hostility, fear, paranoia, and psychosis. Different factors reflect the severity of different symptoms. According to the recent situation and severity of symptoms, the subjects use 1 to 5 grades for self-evaluation, the higher the score is the more serious mental health problems.

\section{Statistical Analysis}

SPSS19.0 software was used for statistical analysis.

\section{RESULtS}

\section{A. Status Quo of Mental Health of Independent College} Students

Chinese scholars proposed the application of SCL-90's cut-off value according to the Chinese norm results, that is, the total score is greater than or equal to 200 points, or the number of positive items (score $\geq 2$ ) exceeds 43 items, or any factor is equal to or greater than 3 points.

TABLE I. INDEPENDENT COLLEGE STUDENTS SCL-90 TEST POSITIVE SCREENING RESULTS

\begin{tabular}{|c|c|c|c|c|}
\hline & $\begin{array}{c}\text { Positive } \\
\text { result }\end{array}$ & $\begin{array}{c}\geq 200 \text { total } \\
\text { points }\end{array}$ & $\begin{array}{c}\text { Factor } \\
\text { average } \\
\geq 3\end{array}$ & $\begin{array}{c}\text { Number of } \\
\text { positive } \\
\text { items } \geq 43\end{array}$ \\
\hline $\begin{array}{c}\text { Number of } \\
\text { people (N) }\end{array}$ & 37 & 18 & 35 & 20 \\
$\begin{array}{c}\text { Proportion } \\
(\%)\end{array}$ & 21.76 & 10.59 & 20.59 & 11.76 \\
\hline
\end{tabular}

B. Comparison between independent college students and national norms

It can be seen from Table 2 that the scores of interpersonal sensitivity, hostility, somatization, compulsion and anxiety factors of independent college students are significantly higher than those of domestic youth norms, while the scores of other factors are not statistically significant.

TABLE II. COMPARISON BETWEEN SCL-90 SCORES OF INDEPENDENT COLLEGE STUDENTS AND NATIONAL YOUTH NORMS.

\begin{tabular}{|c|c|c|}
\hline Symptomatic factor & Independent college student & National youth norm \\
\hline Somatization & $1.52 \pm 0.48$ & $1.34 \pm 0.45^{*}$ \\
\hline Compulsion & $2.12 \pm 0.71$ & $1.69 \pm 0.611^{* *}$ \\
\hline $\begin{array}{c}\text { Interpersonal } \\
\text { Sensitivity }\end{array}$ & $2.07 \pm 0.74$ & $1.76 \pm 0.67$ ** \\
\hline Depression & $1.64 \pm 0.55$ & $1.57 \pm 0.61$ \\
\hline Anxiety & $1.89 \pm 0.68$ & $1.42 \pm 0.43^{* *}$ \\
\hline
\end{tabular}




\begin{tabular}{|c|c|c|}
\hline \multicolumn{3}{|c|}{ Cont. TABLE II. } \\
\hline Hostility & $1.66 \pm 0.58$ & $1.50 \pm 0.57 *$ \\
\hline Fear & $1.36 \pm 0.63$ & $1.33 \pm 0.45$ \\
\hline Paranoia & $1.52 \pm 0.55$ & $1.52 \pm 0.6$ \\
\hline Psychotic & $1.38 \pm 0.59$ & $1.36 \pm 0.47$ \\
\hline
\end{tabular}

\section{Differences in grades of independent college students SCL-90}

TABLE III. TABLE SCORE ONGRADE DIFFERENCE 3 LARGE INDEPENDENT COLLEGE STUDENTS SCL-90

\begin{tabular}{|l|l|l|l|l|l|}
\hline $\begin{array}{l}\text { SCL-90 } \\
\text { factor }\end{array}$ & A large & Sophomore & Junior & Senior & $\mathrm{F}$ \\
\hline Somatization & $1.47 \pm 0.56$ & $1.31 \pm 0.31$ & $1.17 \pm 0.29$ & $1.68 \pm 0.52$ & 12.947 \\
\hline $\begin{array}{l}\text { Interpersonal } \\
\text { sensitivity }\end{array}$ & $1.90 \pm 0.53$ & $2.11 \pm 0.74$ & $2.27 \pm 0.79$ & $1.90 \pm 0.78$ & $2.144^{*}$ \\
\hline hostility & $1.53 \pm 0.50$ & $1.47 \pm 0.43$ & $1.27 \pm 0.26$ & $1.40 \pm 0.35$ & $3.428^{* *}$ \\
\hline Compulsion & $2.10 \pm 0.64$ & $2.23 \pm 0.74$ & $2.14 \pm 0.71$ & $2.02 \pm 0.75$ & $.900^{* *}$ \\
\hline Depression & $1.83 \pm 0.61$ & $1.51 \pm 0.35$ & $1.50 \pm 0.47$ & $1.75 \pm 0.65$ & $3.769^{*}$ \\
\hline anxiety & $2.10 \pm 0.71$ & $2.02 \pm 0.60$ & $1.91 \pm 0.79$ & $1.71 \pm 0.55$ & $2.766^{*}$ \\
\hline Hostility & $1.22 \pm 0.24$ & $1.20 \pm 0.24$ & $1.18 \pm 0.26$ & $1.40 \pm 0.43$ & 5.228 \\
\hline Paranoia & $1.45 \pm 0.47$ & $1.18 \pm 0.29$ & $1.20 \pm 0.25$ & $1.30 \pm 0.35$ & $4.559^{* *}$ \\
\hline Psychotic & $1.28 \pm 0.32$ & $1.13 \pm 0.23$ & $1.12 \pm 0.19$ & $1.35 \pm 0.32$ & $7.787^{*}$ \\
\hline
\end{tabular}

TABLE IV. POST-TESTING OF DIFFERENCES IN GRADES OF SCL-90 SCORES OF INDEPENDENT COLLEGE STUDENTS

\begin{tabular}{|c|c|c|c|}
\hline Dependent variable & (I) Grade & (J) Grade & Significant \\
\hline \multirow{6}{*}{ Compulsion } & \multirow{3}{*}{ Freshman } & Sophomore & .305 \\
\hline & & Junior & .746 \\
\hline & & Senior & .635 \\
\hline & \multirow{2}{*}{ Sophomore } & Junior & .417 \\
\hline & & Senior & .110 \\
\hline & Junior & Senior & .363 \\
\hline \multirow{6}{*}{ Interpersonal sensitivity } & \multirow{3}{*}{ Freshman } & Sophomore & .305 \\
\hline & & Junior & .746 \\
\hline & & Senior & .635 \\
\hline & \multirow{2}{*}{ Sophomore } & Junior & .363 \\
\hline & & Senior & .448 \\
\hline & Junior & Senior & .051 \\
\hline \multirow{6}{*}{ Hostility } & \multirow{3}{*}{ Freshman } & Sophomore & .305 \\
\hline & & Junior & .746 \\
\hline & & Senior & .635 \\
\hline & \multirow{2}{*}{ Sophomore } & Junior & .028 \\
\hline & & Senior & .454 \\
\hline & Junior & Senior & .082 \\
\hline \multirow{5}{*}{ Anxiety } & Freshman & Sophomore & .305 \\
\hline & & $\begin{array}{l}\text { Junior } \\
\text { Senior }\end{array}$ & .203 \\
\hline & \multirow[b]{2}{*}{ Sophomore } & Junior & .484 \\
\hline & & Senior & .045 \\
\hline & Junior & Senior & .128 \\
\hline \multirow{6}{*}{ Depression } & \multirow{3}{*}{ Freshman } & Sophomore & .305 \\
\hline & & Junior & .746 \\
\hline & & Senior & .635 \\
\hline & \multirow{2}{*}{ Sophomore } & Junior & .942 \\
\hline & & Senior & .055 \\
\hline & Junior & Senior & .020 \\
\hline \multirow{6}{*}{ Paranoia } & \multirow{3}{*}{ Freshman } & Sophomore & .002 \\
\hline & & Junior & .001 \\
\hline & & Senior & .045 \\
\hline & \multirow{2}{*}{ Sophomore } & Junior & .087 \\
\hline & & Senior & .043 \\
\hline & Junior & Senior & .129 \\
\hline \multirow{6}{*}{ Mental illness } & \multirow{3}{*}{ Freshman } & Sophomore & .028 \\
\hline & & Junior & .008 \\
\hline & & Senior & .011 \\
\hline & \multirow{2}{*}{ Sophomore } & Junior & .085 \\
\hline & & Senior & .010 \\
\hline & Junior & Senior & 635 \\
\hline
\end{tabular}

There were significant differences in the seven factors of interpersonal sensitivity, hostility, compulsive, depression, anxiety, paranoia and psychosis in SCL-90 among independent college students of different grades.(ranking of freshmen, sophomores, juniors, seniors)

\section{Gender differences in SCL-90 scores of independent college students}

TABLE V. DIFFERENCES BETWEEN INDEPENDENT COLLEGE STUDENTS OF DIFFERENT GENDERS ON SCL-90

\begin{tabular}{|c|c|c|c|}
\hline SCL-90 factor & male & Female & $\mathrm{t}$ \\
\hline Somatization & $1.40 \pm 0.49$ & $1.45 \pm 0.48$ & 0.448 \\
\hline Interpersonal sensitivity & $2.12 \pm 0.78$ & $2.02 \pm 0.68$ & 0.751 \\
\hline Hostility & $1.37 \pm 0.41$ & $1.44 \pm 0.34$ & 1.077 \\
\hline Compulsion & $2.10 \pm 0.74$ & $2.15 \pm 0.69$ & 0.118 \\
\hline Depression & $1.61 \pm 0.61$ & $1.70 \pm 0.47$ & 1.134 \\
\hline Anxiety & $1.85 \pm 0.69$ & $1.99 \pm 0.66$ & $1.658 * *$ \\
\hline Hostility & $1.21 \pm 0.35$ & $1.35 \pm 0.30$ & 7.235 \\
\hline Paranoia & $1.23 \pm 0.35$ & $1.34 \pm 0.33$ & $4.295^{*}$ \\
\hline Psychotic & $1.21 \pm 0.27$ & $1.25 \pm 0.31$ & $.767 *$ \\
\hline
\end{tabular}

There are significant differences in the three factors of anxiety, paranoia and psychosis among independent college students of different genders.

\section{DisCUSSION}

This study shows that the independent college students have statistical significance compared with the domestic norm in terms of somatization, coercion, interpersonal sensitivity, anxiety, hostility, which indicates that the mental health level of independent college students is lower than that of ordinary college students. To be worse, this is reflected in the average value of the four factors of college students' depression, fear, paranoia and psychosis in colleges and universities is slightly lower than the national norm.

The research shows that the influential factors of mental health problems of independent college students mainly exist in life and learning. In learning, the pressure of learning is too great, and the students are tired of learning. The students of independent colleges are mostly students with poor grades and weak learning foundations. During the visit, many students just came to the college with the attitude of taking an undergraduate diploma, and if someone chooses to go to the library to study in the dormitory, they often get ridicule from others. From the results of the college entrance examination, the scores of independent college students are quite different from those of public universities and key universities. Through the comparison of scores, it can be seen that the students of independent colleges have problems in the learning methods and abilities. For a long time, students are inevitably tired of learning, and slowly appear absenteeism, playing mobile phones in class and other problems. In life, most independent colleges come from cities, and the proportion of only-child families in cities is higher than in rural areas. These students are usually the focus of the family. In addition, there are certain economic factors. Some students have long lived in a favored environment and have a strong psychological advantage. After entering college, they still bring this sense of superiority to campus life, but all the student groups in the university are 
equal. In this environment, these favored students at home are difficult to adapt to this gap, causing certain psychological imbalances. In addition, in the collective dormitory environment, it is impossible to follow their own wishes everywhere, but because of the pampering at home, students do not know how to respect the interests of others and only know how to maximize their own interests. hey focus on the interests of the individual, and it is difficult to have a spirit of selflessness. Without team spirit and collective consciousness, and not interested in school and class activities, the entire campus life is separated from the class and classmates, causing them to slowly fade out of the collective life. In the long run, independent college students are more likely to suffer major setbacks in life and study, and can not get rid of the bad influence for a long time, thus showing mental symptoms such as anxiety, interpersonal sensitivity, and obsessive-compulsive disorder.

This is because college students of independent colleges face more complex problems than their peers. On the one hand, college students need to establish new interpersonal relationships to adapt to the new environment. On the other hand, the cultural inheritance relationship between the universities holding independent colleges and independent colleges makes the college students of independent colleges have more yearning for the university and be disappointed about their own environment, resulting in more psychological conflicts. Students who are suffering from major setbacks in university study and life are most likely to have psychological barriers, followed by family poverty, interpersonal sensitivity and love failure. With the changes in social structure and the changes in the group environment, the independent college students are far away from their parents and hometowns, lack of spiritual support, and often helpless. Faced with high tuition fees and indifferent interpersonal relationships, they lack channels to express their confusion, depression, and dissatisfaction. Especially when there is a problem with love, it is often in a state of helplessness, and it is impossible to relieve the distress. These employment pressures, tuition pressures, and academic pressure are the main reasons for the high symptom factor of SCL-90.

According to the study, gender is related to the four factors of somatization, depression, fear and paranoia. Generally speaking, girl's nature is sensitive, consider the problem more delicately, and care about other people's evaluations. Girls' psychological conflicts experience are more than boys, Some small things can also easily lead to negative emotional reactions, often affecting their own state of life, and even have different levels of negative impact on their classmates. Boys are generally reluctant to reveal their inner contradictions. When contradictions accumulate to a considerable extent, they are prone to erupt and manifest in relatively extreme ways, which will seriously affect the psychological state of themselves and their surrounding classmates and relatives.
Grade negatively correlated with hostility, paranoia and depression, It shows that with grade growth, independent college students' anti-pressure abilities are also gradually increasing, Compared to a large newly enrolled freshmen, the senior students have increased their life experience, have a more comprehensive and deeper understanding of themselves and society, master more skills in interpersonal communication, and form a more stable interpersonal relationship net, becoming confident and mature, has been relatively adapted to college life. The students in the lower grades have shorter school hours and are not familiar with the people and environment around them, lacking sufficient emotional support for study and life, and they need help and knowledge in the face of things that need to be dealt with. They need time to adjust to the new situation. Psychological problems such as somatization, compulsion, depression, and interpersonal sensitivity are inevitable.

\section{CONCLUSION}

In summary, the psychological status of college students in independent colleges is lower than that of ordinary college students. When conducting independent mental health education, independent colleges should fully consider the their students' particularity of learning, life style, interpersonal relationships, etc. to understand the mental health status of students, constantly improve the mental health management mechanism, and improve the mental health of independent college students.

\section{REFERENCES}

[1] Chen Ping, Wang Yibin, Feng Dingding, Luo Qiang. Analysis of the current situation of college students' mental health in independent colleges and its countermeasures [J]. Education Modernization, 2019, 6 (06): 148-150. (In Chinese)

[2] Zeng Gui, Xie Liping. Investigation Report on Mental Health Status of College Students in Independent College-Taking the Foreign Trade College of Chongqing Normal University as an Example[J]. Journal of Jilin Engineering and Technology Teachers College, 2017, 33(07): 94-96. (In Chinese)

[3] YAN Ling, HU Wei, LIU Jingjing. Investigation Report on Mental Health Education of College Students in Independent College-Taking an Independent College in Wuhan as an Example[J].Journal of Clinical Medical Literature, 2017, 4(04): 654. (In Chinese)

[4] Zhou Dapeng. Analysis of the Mental Health of College Students in Independent Colleges[J].Henan Education (High Education), 2013(06): 74-75. (In Chinese)

[5] Yang Kai, Wang Xiaqiang, Gu Yongjian. Evaluation of psychological intervention effect of new students in a private college[ $\mathrm{J}]$.Chinese School Health,2011,32(08):1004-1005. (In Chinese)

[6] ZHOU Yangen. Mental Health Problems of Impoverished College Students in Independent College and Educational Countermeasures-Based on Positive Psychology[J].Modern Preventive Medicine,2010,37(17):3279-3280+3283. (In Chinese) 